\begin{tabular}{|c|c|c|}
\hline & Benha Veterinary Medical Journal & 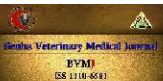 \\
\hline $\begin{array}{l}\text { Official Journal Issued by } \\
\text { Faculty of } \\
\text { Veterinary Medicine }\end{array}$ & Journal homepage: https://bvmj.journals.ekb.eg/ & $\begin{array}{c}3-5= \\
\text { Since 1990 }\end{array}$ \\
\hline
\end{tabular}

\title{
The effect of thyme (thymus vulgaris) extract on Escherichia coli in diarrheic calves with study of its immunological effect
}

\author{
Ashraf A. Abd El Tawab ${ }^{1}$, Fatma I. El-Hofy ${ }^{1}$, Wael M. Wafa ${ }^{2}$, Yasmeen M. Bedawy ${ }^{2}$ \\ ${ }^{1}$ Department of Bacteriology, Immunology and Mycology, Faculty of Veterinary Medicine, Benha University, Egypt \\ ${ }^{2}$ Department of Cattle Breeding, Animal Production Research Institute, El Gemisa station, Elgharbia, Egypt
}

\section{ARTICLE INFO}

Keywords

Calves

E. Coli

Immunity

Thyme

\begin{abstract}
The current study was designed to examine the antibacterial effect of thyme (thymus vulgaris) on Escherichia coli in diarrheic calves and also the effect of the thyme as immunostimulant Collection of 100 rectal swabs from 100 diarrheic calves was done for isolation and identification of $E$. coli and serotyping of the bacterial isolates followed by their antibiotic sensitivity testing and determination of MIC and MBC of thyme oil on them. Supplementation of thyme extract to Friesian calves' milk was done and examined its effect of on their immunity by antibodies titration of IgM, IgG and IgA in their serum. Results revealed that the incidence of $E$. coli was $58 \%$ and pathogenic $E$. coli was $46 \%$. The most predominant serotype was 0125 . The highly resistance of the strains was against oxytetracycline (OT) and ampicillin (AMP). The thyme had antibacterial effect against $E$. coli strains by MIC ranged from 5 to $320 \mu \mathrm{g} / \mathrm{ml}$, but the MBC was negative for all strains and the thyme extract at $40 \mathrm{mg} / \mathrm{kg}$ body weight improved the immunity as it significantly $(\mathrm{P} \leq 0.05)$ increased $\operatorname{IgM}, \operatorname{IgG}$ and IgA titre in calves serum
\end{abstract}

\section{INTRODUCTION}

Diarrhea is one of the major mortality reasons in newborn calves, the incidence rate of diarrhea among calves at first month of age was ranged from 15 to $20 \%$, this indicated that the great risk occurs during the first two weeks of calves life (Vandeputte et al., 2010). E. coli is one of the most important bacteria, causing diarrhea in newly-born calves during the first two weeks of life and characterized by watery faeces with rapid onset followed by high mortality (Yeshiwas and Fentahun, 2017).

The $\mathrm{O}$-antigen is one of the molecules used in serotyping of E. coli. Up dated data described, more than 180 different Oserotypes but not even half of them have been structurally elucidated (Stenutz et al., 2006).

For several years' antibiotics were excessive used not only to control pathogens but also to enhancement the calves growth rate (Santos et al., 2015). The overuse of antibiotics in order to reduce these pathogens has led to the phenomenon of multi-drug resistant bacteria (Boskovic et al., 2013). Bacterial resistance increased worldwide and become one of the major causes of treatment failure of infectious diseases so herbal medicine using plant extracts as plant essential oils are interesting alternatives to antibiotic for the control of microbial infections (Lopez-Romero et al., 2015).

The thyme had numerous beneficial effects as antimicrobial, antioxidative, carminative, and antiseptic properties (Baranauskiene et al., 2003). The Thyme oil is composed of many chemical compounds including thymol, caryophyllene, and pinene which are biologically active compounds used in treatment of various diseases so, the Thymus vulgaris can be used as a new potential source of medicinal plant extracts for the treatment of various types of illness due to presence of many bioactive compounds (AlAsmari et al., 2017).

The essential oils enable to breakdown the lipids of the cell membrane of the bacteria and mitochondria because of their hydrophobicity characteristic and leading to cell structures disturbing and rendering them more permeable (Sikkema et al., 1994).

The essential oil from Thyme (Thymis vulgaris L.) has antibacterial activities against six Gram-positive and Gramnegative pathogenic bacteria: Escherichia coli, Staphylococcus aureus, S. epidermidis, Streptococcus spp, and Pantoa spp. The results showed that essential oil obtained from thyme has a range of MIC values from 0.33 to $2.67 \mathrm{mg} / \mathrm{mL}$ (Imelouane et al., 2009).

Also, the oregano water (OW) that has high amount of thymol $(5.7 \mathrm{~g} / \mathrm{kg})$ had protentional effect on level of immunoglobulin (IgA, IgG and IgM) in calves (Ozkaya et al., 2018).

Therefore, the aim of the work was to determine the minimum inhibitory concentration (MIC) and minimum bactericidal concentration (MBC) of the thyme on $\mathrm{E}$. coli isolated from diarrheic calves and also to determine the effect of the thyme on the immune status.

\footnotetext{
* Corresponding author: Yasmeen M. Bedawy, Department of Cattle Breeding, Animal Production Research Institute, El Gemisa station, Elgharbia, Egypt
} 


\section{MATERIAL AND METHODS}

\subsection{Samples:}

One hundred rectal swabs were collected from 100 cow diarrheic calves 0-3 months of age from El-Gemizah Animal Production Research Station farm at El-Gharbeia government using sterile swabs and inoculated in nutrient broth. All samples were collected under a septic condition and safety precautions. The clinically examined animals suffered from listlessness, abdominal pain, watery yellow diarrhea and normal temperature. Severely infected calves showed signs of severe enteritis like bloody diarrhea, stop of suckling, fever, dehydration and dry skin. Samples of fecal swabs were labeled and stored in ice box then transported rapidly to the laboratory and examined bacteriologically for isolation and identification of Escherichia coli (E. coli).

\subsection{Bacteriological examination of the samples:}

Swabs were inoculated separately into nutrient broth and incubated at $37{ }^{\circ} \mathrm{C}$ for $18 \pm 2 \mathrm{~h}$ under aerobic condition as described previously by Quinn et al. (2002). A loopful from the broth of each sample was streaked onto nutrient agar, MacConkey's agar and Eosin Methylene Blue agar. The inoculated plates were incubated at $37{ }^{\circ} \mathrm{C}$ for $24 \mathrm{hrs}$. A loopful of colony was stained with Gram's stain for microscopic examination.

\subsubsection{Biochemical Identification of E. coli:}

Biochemical identification of $E$. coli was done according to Koneman et al. (1997) and Quinn et al., (2002) including Indole test, Methyl red test, Voges -Proskauer test, Citrate utilization test, Triple sugar iron, Sugar fermentation test, urease test, Oxidase test, Catalase test, Nitrate Reduction test, Eijkman test.

\subsubsection{Detection of pathogenic and hemolytic E. coli:}

2.2.2.1. Cultivation on congo red agar (CRA):

A loopful from each isolate was cultivated on the surface of the agar and incubated at $37^{\circ} \mathrm{C}$ for 24 hours. The reaction was recorded at 18, 24, 48 and 72 hours. Appearance of red colonies within 72 hours was recorded as a positive reaction (invasive bacteria), while Negative colonies (noninvasive bacteria) did not bind the dye and remained white even after 72 hours (Berkhoff and Vinal 1986).

2.2.2.2. Cultivation on Blood agar (MacFaddin, 1980):

A loopful from each isolate was cultivated on the surface of the blood agar and incubated at $37^{\circ} \mathrm{C}$ for 24 hours to determine the hemolytic $E$. coli strains (appears as translucent white or yellow colonies surrounded by halo zone)

\subsubsection{Serological identification of E. coli:}

The isolates of $E$. coli were sero-grouped using Sifin antisera (Berlin, Germany) by using slide agglutination test as describe by Edwards and Ewing (1972). Polyvalent and monovalent diagnostic $E$. coli antisera were used. According to somatic (O) they included (8) vials of polyvalent and (43) vials monovalent antisera.

2.3. Antibiotic sensitivity test by disk diffusion method. The following antibiotic disks: gentamycin $10 \mu \mathrm{g}$, ampicillin $10 \mu \mathrm{g}$, ciprofloxacin $5 \mu \mathrm{g}$, chloramphenicol $30 \mu \mathrm{g}$, erythromycin $15 \mu \mathrm{g}$, oxytetracycline $30 \mu \mathrm{g}$, amoxicillin clavulanic acid $30 \mu \mathrm{g}$, cefotaxime $30 \mu \mathrm{g}$ were used to examine the sensitivity of isolated $E$. coli strains according to Finegold and Martin (1982) and interpreted according to CLSI (2016) but erythromycin according to CLSI (2011).

\subsection{Determination of MIC of thyme oil:}

The oil was extracted from the thyme by hydrodistillation method of extraction as the dried aerial parts of the plant were submitted to hydrodistillation for $3 \mathrm{hrs}$ using Clevenger type apparatus, according to the European Pharmacopoeia (1996). The essential oil was collected and stored at $4{ }^{\circ} \mathrm{C}$ until used for determination of minimum inhibitory concentration (MIC) and minimum bactericidal concentration (MBC) of thyme oil against the $E$. coli strains according to CLSI (2009) by weighting $1.024 \mathrm{~g}$ of essential oil in sterile $15 \mathrm{ml}$ falcon tube, next add 5\% DMSO till reach $10 \mathrm{ml}$ and mix well using a vortex, then transfer $2 \mathrm{ml}$ from it to another $15 \mathrm{cc}$ falcon tube contain $8 \mathrm{ml}$ Muller Hinton Broth II then the prepared medium (Muller Hinton Broth II) were dispensed $(100 \mu \mathrm{l} /$ well) into sterile $\mathrm{U}$ bottom 96 well micro titer plates, by using multichannel pipette to dispense $100 \mu \mathrm{l}$ of medium into all wells of micro-titer plate, labeled the plates and lid. Next $100 \mu \mathrm{l}$ of a before mentioned prepared essential oil were dispensed into the wells of column one only (far left of the plate). Using multichannel pipette set at $100 \mu \mathrm{l}$, mix the essential oil and Muller Hinton Broth II into the well in column 1 by sucking up and down 8-10 times (don't splash) then withdraw $100 \mu 1$ from column 1 and add them to column 2 this makes column 2 a twofold dilution of column 1, mix up and down 8-10 times then transfer $100 \mu$ to column 3 , repeat the procedure down to column 11 only and discard $100 \mu 1$ from column 11 rather than putting in column 12 (control positive), final essential oil concentration were ranged from $5-5120 \mu \mathrm{g} / \mathrm{ml}$ then bacterial inoculums was Prepared, suspensions equivalent to the no 3.0 McFarland turbidity standard were adjusted by visual examination using McFarland card and inoculation of approximately $4.5 \times 105 \mathrm{CFU} / \mathrm{ml}$ were prepared with sterile $0.85 \% \mathrm{NaCl}$.After preparation of bacterial inoculums, bacteria poured into sterile Petri dish. With multichannel pipette $100 \mu \mathrm{l}$ of each of bacterial inoculums was dispensed to each well then cover by lid and incubation to the plates at $35^{\circ} \mathrm{c}$ for $16-18 \mathrm{~h}$. The MIC before adding the resazurin indicator was defined as the lowest concentration of the antimicrobial agent that inhibited visible growth. A change indicates the reduction of and, therefore bacterial growth .The MIC after adding resazurin indicator was defined as the lowest essential oil concentration that prevented the color change of resazurin from blue to pink (Palomino et al ., 2002).Determination of $\mathrm{MBC}$ of essential oil on the susceptible isolates by the following method: From each susceptible isolate take $100 \mu \mathrm{l}$ from last 3 wells that showing inhibition of bacteria, dispense those $100 \mu \mathrm{l}$ into sterile Eppendorf tube containing $900 \mu 1$ of normal physiological saline and mix well, next $100 \mu \mathrm{l}$ from last tube were transferred to another sterile Eppendorf containing also 900 $\mu \mathrm{l}$ of normal physiological saline then take $100 \mu \mathrm{l}$ from each Eppendorf and culture them into Petridis containing nutrient agar. So that each well becomes cultured on two dishes and so every susceptible isolate become cultured on six dishes. Incubation of dishes at $37{ }^{\circ} \mathrm{C}$ for $24 \mathrm{hr}$ then they were examined for bacterial growth. MBC defined as the lowest concentration of the antimicrobial agent that prevents visible growth/kill bacteria. 
2.5. Determination the effect of thyme extract on immune status of calves:

A total of 15 newly born male and female healthy calves were used in this study with average live body weight of $35.07 \mathrm{~kg}$ at birth. Animals were divided into three groups, five suckling calves in each. Calves in the $1^{\text {st }}$ group were fed on two whole cow milk meals at 6.0 a.m. and 6.0 p.m. and the starter was given with good quality berseem hay (Trifolium alexandrinum) after the second week of age this group considered as a control group. Calves in $2^{\text {nd }}$ group were fed on the same meal of control group and supplemented with thyme extract (TE) at a level of $20 \mathrm{mg} / \mathrm{kg}$ B. Wt. according to Vakili et al. (2013). Calves in the $3^{\text {rd }}$ group were supplemented with the double dose $(40 \mathrm{mg} / \mathrm{kg}$ $\mathrm{BW}$ of TE). Immunoglobulins ( $\mathrm{IgG}, \operatorname{IgM}$ and $\operatorname{IgA}$ ) concentrations in blood serum samples were recorded at the start experimental age (3 days of age), 30, 60, $90 \mathrm{~d}$ of age and $105 \mathrm{~d}$ (weaning age) using the quantitative ELISA (Bovine IgG, IgM, and IgA ELISA Quantitative kit, Bethyl laboratories, UK) as descripted by Killingsworth and Savory (1972).

\subsection{Statistical analysis}

Statistical analysis was done by using SPSS analysis program (SPSS ver. 15, 2010). The data of the presented experimental work were analyzed. The significant differences which were detected were performed at $(\mathrm{P} \leq 0.05)$ using Duncan Multiple Range Test (Duncan, 1955).

\section{RESULTS}

Bacterial isolation and identification

The bacteriological examination of 100 fecal samples recovered that the number of $E$. coli isolates was 58 with an infection rate $58 \%$ divided into $46 \%$ pathogenic E. coli isolates and $12 \%$ nonpathogenic.

\section{Sero-grouping of E.coli isolates.}

By using monovalent antisera 3 identified serogroups of E.coli were $\mathrm{O}_{125}, \mathrm{O}_{158}$ and $\mathrm{O}_{86 \mathrm{a}}$ as five isolates were $\mathrm{O}_{125}$ $(50 \%)$, four isolates were $\mathrm{O}_{86 \mathrm{a}}(40 \%)$ and one isolate was $\mathrm{O}_{158}(10 \%)$

Antibiotic sensitivity test for E.coli isolates.

E.coli strains, were resistant to oxytetracycline (90\%) followed by ampicillin $(80 \%)$, chloramphenicol $(60 \%)$ and cefotaxim (30\%), while E.coli strains were $100 \%$ sensitive to gentamycin and ciprofloxacin followed by $40 \%$ to amoxicillin/clavulanic acid and cefotaxime as shown in table (1).

Minimum inhibitory concentration (MIC) and Minimum bactericidal concentration (MBC) of thyme oil against E.coli.

MIC and MBC of thyme oil against E.coli isolates shown in table (2). Thyme oil was found to be effective against $E$.coli $\mathrm{O}_{158}$ by MIC $40 \mu \mathrm{g} / \mathrm{ml}$, E.coli $\mathrm{O}_{86 a}$ by MIC ranged from 5 to 80 to $320 \mu \mathrm{g} / \mathrm{ml}$ and E.coli $\mathrm{O}_{125}$ by MIC ranged from 5 to 80 to 160 to $320 \mu \mathrm{g} / \mathrm{ml}$. while found to be effective against reference strain of E.coli by MIC $320 \mu \mathrm{g} / \mathrm{ml}$. The MBC was negative in all strains even in the reference strain.
The effect of thyme extract on the immune status of calves.

\begin{tabular}{|c|c|c|c|c|c|c|c|c|c|}
\hline \multirow{4}{*}{$\begin{array}{l}\text { No of } \\
\text { Sampl } \\
\text { e }\end{array}$} & \multirow{4}{*}{$\begin{array}{l}\text { E.coli } \\
\text { strain } \\
\mathrm{s}\end{array}$} & \multicolumn{8}{|c|}{ Antibiotic disks } \\
\hline & & OT & CI & CTX & & $\mathrm{AM}$ & $\mathrm{CN}$ & & \\
\hline & & $30 \mu$ & $P_{54}$ & $30 \mu$ & & $\begin{array}{l}\text { C } \\
30 \text { or }\end{array}$ & $10 \mu$ & $15 \mu$ & 30 \\
\hline & & $\mathrm{g}$ & $5 \mu$ & $\mathrm{g}$ & $10 \mu \mathrm{g}$ & $30 \mu \mathrm{g}$ & $\mathrm{g}$ & $\mathrm{g}$ & $\mathrm{g}$ \\
\hline 1 & $\mathrm{O}_{125}$ & $\mathrm{R}$ & s & I & $\mathrm{R}$ & I & $\mathrm{s}$ & I & $\mathrm{R}$ \\
\hline 2 & $\mathrm{O}_{125}$ & $\mathrm{R}$ & s & $\mathrm{R}$ & $\mathrm{R}$ & I & $\mathrm{s}$ & I & $\mathrm{s}$ \\
\hline 3 & Ossa & $\mathrm{R}$ & s & $\mathrm{R}$ & I & $\mathrm{s}$ & $\mathrm{s}$ & I & $\mathrm{s}$ \\
\hline 4 & Ossa & $\mathrm{R}$ & $\mathrm{s}$ & I & $\mathrm{R}$ & $\mathrm{s}$ & $\mathrm{s}$ & I & $\mathrm{R}$ \\
\hline 5 & $\mathrm{O}_{125}$ & $\mathrm{~s}$ & s & $\mathrm{s}$ & $\mathrm{s}$ & $\mathrm{s}$ & $\mathrm{s}$ & I & I \\
\hline 6 & Osfa & $\mathrm{R}$ & s & $\mathrm{R}$ & $\mathrm{R}$ & I & $\mathrm{s}$ & I & $\mathrm{R}$ \\
\hline 7 & $\mathrm{O}_{125}$ & $\mathrm{R}$ & $\mathrm{s}$ & $\mathrm{s}$ & $\mathrm{R}$ & I & $\mathrm{s}$ & I & $\mathrm{s}$ \\
\hline 8 & Os6a & $\mathrm{R}$ & s & $\mathrm{s}$ & $\mathrm{R}$ & I & $\mathrm{s}$ & I & $\mathrm{R}$ \\
\hline 9 & $\mathrm{O}_{125}$ & $\mathrm{R}$ & s & I & $\mathrm{R}$ & I & $\mathrm{s}$ & $\mathrm{s}$ & $\mathrm{R}$ \\
\hline 10 & $\mathrm{O}_{1 s 8}$ & $\mathrm{R}$ & s & $\mathrm{s}$ & $\mathrm{R}$ & $\mathrm{s}$ & $\mathrm{s}$ & I & $\mathrm{R}$ \\
\hline \multirow{3}{*}{$\begin{array}{l}\text { Result } \\
\text { s }\end{array}$} & $\mathrm{S}$ & 1 & 10 & 4 & 1 & 4 & 10 & 1 & 3 \\
\hline & I & - & - & 3 & 1 & 6 & - & -9 & 1 \\
\hline & $\mathrm{R}$ & 9 & - & 3 & 8 & - & - & - & 6 \\
\hline
\end{tabular}

OT: Oxy R: Resistant. I: Intermediate. S: Sensitive

The results presented in table (3) revealed that, blood immunoglobulins IgG, IgM and IgA levels of calves at the beginning of experimental work (pretreatment period) did not differ significantly $(\mathrm{P} \leq 0.05)$ among groups.

The values of IgG clearly increased significantly $(\mathrm{P} \leq 0.05)$ in G3 compared to G1 or G2 and no significant difference in G2 calves compared to those in G1, this trend reflect the significant effect of thyme extract at $40 \mathrm{mg} / \mathrm{kg}$ body weight at all periods.

Calves in G3 showed the highly significant values of $\operatorname{IgM}$ levels in compared to control ones. Also, calves in G2 reached a significant $(\mathrm{P} \leq 0.05)$ increase of their $\mathrm{IgM}$ values as compared to those in $\mathrm{G} 1$ but the differences between $\mathrm{G} 2$ and G3 was insignificant except post 30 days of treatment stage, data showed G3 recorded the highest value $(2.72 \mathrm{~g} / \mathrm{l})$ compared to G2 (2.04 g/l) or G1 (1.77 g/l).

Immunoglobulin type A levels was clearly higher in G3 followed by G2 and finally G1 and there was no significant difference between $\mathrm{G} 1$ and $\mathrm{G} 2$, while the values at 60 and 90 days post treatment, there were clearly significant $(\mathrm{P} \leq 0.05)$ increase in the serum IgA levels of calves in G3 compared to those in $\mathrm{G} 1$ but the $\mathrm{G} 2$ had the moderate values

\begin{tabular}{llll}
\multicolumn{5}{l}{$\begin{array}{l}\text { Table } 2 \text { Minimum inhibitory concentration }(\mathrm{MIC}) \text { and Minimum } \\
\text { bactericidal concentration }(\mathrm{MBC})\end{array}$} \\
\hline NO of sample & E.coli strains & MIC $(\mu \mathrm{g} / \mathrm{ml})$ & MBC $(\mu \mathrm{g} / \mathrm{ml})$ \\
\hline 1 & E.coli $\mathrm{O}_{158}$ & 40 & Negative \\
2 & E.coli $\mathrm{O}_{86 \mathrm{a}}$ & 80 & Negative \\
3 & E.coli $\mathrm{O}_{86 \mathrm{a}}$ & 80 & Negative \\
4 & E.coli $\mathrm{O}_{86 \mathrm{a}}$ & 5 & Negative \\
5 & E.coli $\mathrm{O}_{86 \mathrm{a}}$ & 320 & Negative \\
6 & E.coli $\mathrm{O}_{125}$ & 80 & Negative \\
7 & E.coli $\mathrm{O}_{125}$ & 160 & Negative \\
8 & E.coli $\mathrm{O}_{125}$ & 320 & Negative \\
9 & E.coli $\mathrm{O}_{125}$ & 5 & Negative \\
10 & E.coli $\mathrm{O}_{125}$ & 160 & Negative \\
11 & Reference strain & 320 & Negative \\
\hline
\end{tabular}


Table 3 Means and standard errors of immunoglobulin G ( $\mathrm{g} / \mathrm{l})$ of growing calves at different experimental periods.

\begin{tabular}{lcccc}
\hline Period & \multicolumn{3}{c}{ Treatment group } & Overall mean \\
& G1 & G2 & G3 & \\
\hline Pretreatment & $25.13 \pm 0.23$ & $25.18 \pm 0.31$ & $25.33 \pm 0.19$ & $25.21 \pm 0.13$ \\
Post 30d & $20.83 \pm 0.77^{\mathrm{b}}$ & $21.13 \pm 1.16^{\mathrm{b}}$ & $23.93 \pm 0.26^{\mathrm{a}}$ & $21.96 \pm 0.60$ \\
Post 60d & $16.83 \pm 0.97^{\mathrm{b}}$ & $17.68 \pm 0.69^{\mathrm{b}}$ & $20.58 \pm 0.46^{\mathrm{a}}$ & $18.36 \pm 0.62$ \\
Post 90d & $17.80 \pm 1.01^{\mathrm{b}}$ & $19.13 \pm 0.38^{\mathrm{b}}$ & $22.60 \pm 0.46^{\mathrm{a}}$ & $19.84 \pm 0.71$ \\
Weaning & $18.40 \pm 1.03^{\mathrm{b}}$ & $20.15 \pm 0.46^{\mathrm{b}}$ & $23.95 \pm 0.32^{\mathrm{a}}$ & $20.83 \pm 0.78$ \\
\hline a and b: Means denoted with the same superscripts are not significantly $(\mathrm{P} \leq 0.05)$ differen
\end{tabular}

Table 4 Means and standard errors of immunoglobulin $\mathrm{M}(\mathrm{g} / \mathrm{l})$ of growing calves at different experimental periods.

\begin{tabular}{|c|c|c|c|c|}
\hline \multirow[t]{2}{*}{ Period } & \multicolumn{3}{|c|}{ Treatment group } & \multirow[t]{2}{*}{ Overall mean } \\
\hline & $\mathrm{G} 1$ & $\mathrm{G} 2$ & G3 & \\
\hline Pretreatment & $1.94 \pm 0.12$ & $1.97 \pm 0.13$ & $1.93 \pm 0.10$ & $1.95 \pm 0.06$ \\
\hline Post 30d & $1.77 \pm 0.09^{\mathrm{b}}$ & $2.04 \pm 0.13^{b}$ & $2.72 \pm 0.17^{\mathrm{a}}$ & $2.17 \pm 0.14$ \\
\hline Post 60d & $1.54 \pm 0.08^{\mathrm{b}}$ & $2.02 \pm 0.04^{\mathrm{a}}$ & $2.13 \pm 0.09^{\mathrm{a}}$ & $1.90 \pm 0.09$ \\
\hline Post 90d & $1.25 \pm 0.11^{\mathrm{b}}$ & $2.02 \pm 0.07^{\mathrm{a}}$ & $2.07 \pm 0.14^{\mathrm{a}}$ & $1.78 \pm 0.13$ \\
\hline Weaning & $1.18 \pm 0.08^{\mathrm{b}}$ & $1.80 \pm 0.05^{\mathrm{a}}$ & $1.94 \pm 0.11^{\mathrm{a}}$ & $1.64 \pm 0.11$ \\
\hline \multicolumn{5}{|c|}{$\begin{array}{l}\mathrm{a} \text { and } \mathrm{b} \text { : Means denoted with the same superscripts are not significantly }(\mathrm{P} \leq 0.05) \\
\text { different. }\end{array}$} \\
\hline \multirow[t]{2}{*}{ Period } & \multicolumn{3}{|c|}{ Treatment group } & \multirow[t]{2}{*}{ Overall mean } \\
\hline & G1 & $\mathrm{G} 2$ & G3 & \\
\hline Pretreatment & $0.30 \pm 0.03$ & $0.31 \pm 0.02$ & $0.30 \pm 0.04$ & $0.30 \pm 0.02$ \\
\hline Post 30d & $0.37 \pm 0.04^{b}$ & $0.43 \pm 0.03^{b}$ & $0.59 \pm 0.03^{\mathrm{a}}$ & $0.46 \pm 0.03$ \\
\hline Post 60d & $0.42 \pm 0.03^{b}$ & $0.49 \pm 0.04^{\mathrm{ab}}$ & $0.60 \pm 0.04^{\mathrm{a}}$ & $0.50 \pm 0.03$ \\
\hline Post 90d & $0.57 \pm 0.03^{\mathrm{b}}$ & $0.62 \pm 0.03^{\mathrm{ab}}$ & $0.69 \pm 0.04^{\mathrm{a}}$ & $0.62 \pm 0.02$ \\
\hline Weaning & $0.66 \pm 0.03^{b}$ & $0.71 \pm 0.03^{b}$ & $0.83 \pm 0.03^{\mathrm{a}}$ & $0.73 \pm 0.03$ \\
\hline
\end{tabular}

$\mathrm{a}$ and $\mathrm{b}$ : Means denoted with the same superscripts are not significantly $(\mathrm{P} \leq 0.05)$ different

\section{DISCUSSION}

The clinically examined animals showed mild to severe diarrhea with or without dehydration and weakness signs. The diarrhea was watery in some cases and pasty in other cases and sometimes has foul odor.

Its color ranged from green to yellow to bloody with or without mucous. The infection rate of Escherichia coli $(E$ coli) in the present study was $58 \%$ which was agreed with results obtained by Abou el-ella et al. (2013) who isolated E. coli from calves of 0-4 days-old with an incidence of $57.1 \%$. On the other hand, higher incidence $75.6 \%$ was mentioned by El-Seedy et al. (2016) and lower percentage $17.4 \%$.was detected by Izzo et al. (2011).

In the present study, the result of serotyping of E.coli strains recorded that five isolates were $\mathrm{O}_{125}(50 \%)$ four isolates were $\mathrm{O}_{86 \mathrm{a}}(40 \%)$ and one isolate was $\mathrm{O}_{158}(10 \%)$ the results come in accordance with Mosaad et al. (2008) agreed with Mosaad et al. (2008), who isolated E.coli $\mathrm{O}_{125}, \mathrm{O}_{86}$ from newly born diarrheic calves and Hakim et al. (2017), who identify E.coli $\mathrm{O}_{125}(6.9 \%)$ and $\mathrm{O}_{158}(5.2 \%)$ from diarrheic calves.

Sensitivity test results showed that $E$. coli isolates were $90 \%$ resistant to oxytetracycline, and this result was to certain extent near to the result obtained by Karczmarczyk, et al. (2011) who recorded resistance rate against tetracycline 99\% But lower resistance $63.21 \%$ was detected by Srivani et al. (2017). The results showed that $7 / 10$ of isolates $(70 \%)$ were multidrug resistant to 3 or more antibiotics and this may be due to change in the microbial metabolism and their genetic structure (Blanco et al., 1998) or due to the overuse of antibiotics (Boskovic et al., 2013). Ciprofloxacin showed $100 \%$ sensitivity, and this agreed with Masud et al., (2012), who recorded $100 \%$ sensitivity to Ciprofloxacin and disagreed with Mashak (2018), who recorded 71.42\% resistance.

In the present study, MIC and MBC of thyme oil against $E$. coli was determined. The results revealed that thyme oil was found to be effective against E.coli strains by MIC ranged from 5 to $320 \mu \mathrm{g} / \mathrm{ml}$. The $\mathrm{MBC}$ was negative in all strains even in the reference strain and this result was similar to that detected by Irena et al., (2009) who founded that thyme had the highest antibacterial activities against tested food borne bacteria strains $E$.coli and $S$. Enteritidis by (MIC 640 $\mu \mathrm{g} / \mathrm{cm}$ ). Santurio et al. (2014) found that the geometric means of the MICs was $627.7 \mu \mathrm{g} . \mathrm{m} / \mathrm{L}$ and MBCs was 990.2 $\mu \mathrm{g} / \mathrm{mL}$ against $\mathrm{E}$. coli strains for the thyme essential oil and the MICs was $2786 \mu \mathrm{g} . \mathrm{m} / \mathrm{L}$ and MBCs was $2540 \mu \mathrm{g} / \mathrm{mL}$ for the thymol. The antibacterial activity of thyme oil returned to its contents of thymol and carvacrol, as reported by Helander et al. (1998), who demonstrated that thymol and carvacrol have inhibitory effects on the growth of enteric bacteria E. coli O157:H7 and Salmonella Typhimurium as they have outer membrane disintegration activity and they increased the permeability to ATP through cytoplasmic membrane.

The current results showed that highly significant $(\mathrm{P}<0.05)$ increase in the serum IgM, IgG and IgA values in calves treated by thyme extract in G3 compared to the control which were agreed with Ozkaya et al. (2018), who said that the oregano water (OW) showed a high amount of carvacrol $(994.3 \mathrm{~g} / \mathrm{kg})$ and thymol $(5.7 \mathrm{~g} / \mathrm{kg})$ (the same components of thyme) and examined the effect of supplementing milk replacer (MR) with aromatic oregano (Origanum onite L.) water (OW) on calves and the results showed that the immunoglobulins (IgA, IgG and IgM) values of calves were significantly higher than those of the calves in the Control group.

EOs have a therapeutic potential property that can use in treatment a variety of animal diseases, they act through stimulation of blood circulation, they reduce pathogenic bacterial counts and improve the immunity response by increasing the nutrient digestion and raising essential nutrients availability from intestine (Zeng et al., 2015).

\section{CONCULOSIONS}

It was concluded that the thyme was effective on E.coli as bacteriostatic agent by MIC ranged from 5 to $320 \mu \mathrm{g} / \mathrm{ml}$ but the MBC was negative for all strains and also it improved the immune status of calves as the thyme extract at a level of $40 \mathrm{mg} / \mathrm{kg}$ body weight improved the immunity as it significantly $(\mathrm{P} \leq 0.05)$ increased their serum antibodies titre of $\mathrm{IgG}, \operatorname{IgA}$ and $\operatorname{IgM}$

\section{REFERENCES}

1. Abou el-ella, G.A.; Mohamed, A.M. and Aamer, A.A. (2013): prevalence of enteropathogens associated with neonatal calf scour in cattle and buffalo calves using (fastest $($ strips) rapid field test. Assiut Vet. Med. J., 59 (138): 19-26.

2. Al-Asmari, A.K.; Athar, M.T.; Al-Faraidy, A.A. and Almuhaiza, M.S. (2017): Chemical composition of essential oil of Thymus vulgaris collected from Saudi Arabian market. Asian. Pac. J. Trop. Biomed., 7 (2): 147-150.

3. Baranauskiene, R.; Venskutonis, P.R.; Viskelis, P and Dambrauskiene, E. (2003): Influence of nitrogen fertilizers on the yield and composition of thyme (Thymus vulgaris). Journal of Agricultural and food chemistry, 51: 7751-58.

4. Berkhoff, H. A. and Vinal, A. C. (1986): Congo red medium to distinguish between invasive and noninvasive Escherichia coli pathogenic for poultry. Avian Dis., 30: 117-121. 
5. Blanco, J. E.; Blanco, M.; Mora, A.; Jansen, W.H.; Garcia, V.V.; Azquez, M.L. and Blanco, J. (1998): Serotypes of E. coli isolated from septicemia in chickens in Galicia (northwest Spain). Vet. Microbiol., 61 (3): 229-235.

6. Boskovic, M.; Baltic, Z.M.; Ivanovic, J.; Djuric, J.; Loncina, J.; Dokmanovic M. and Markovic, R. (2013): Use of essential oils in order to prevent foodborne illnesses caused by pathogens in meat. Tehn. Mesa., 54: 14-20.

7. Clinical and Llaboratory Standerds Iinstute (CLSI) (2009): M07. Methods for dilution antimicrobial susceptibility tests for bacteria that grow aerobically. Approved standard, $8^{\text {th }}$ ed. CLSI, Wayne.

8. Clinical and Llaboratory Standerds Iinstute (CLSI) (2011) performance Standards for Antimicrobial Susceptibility Testing; Twenty-second Informational supplement M100S22.

9. Clinical and Laboratory Standerds Iinstute (CLSI) (2016): performance Standards for Antimicrobial Susceptibility Testing; M100S, $26^{\text {th }}$ ed

10. Duncan, D. B. (1955): Multiple range and multiple $F$ test Biometrics, 11: 1-42.

11. Edwards, P.R. and Ewing, W.H. (1972): Edward's and ewing's identification of Enterobacteriace, 3rdEd. Minneapolis, Burgess Publishing Co., 709.

12. El-Seedy, F.R.; Abed, A.H.; Yanni, H.A. and Abd El-Rahman S.A.A. (2016): Prevalence of Salmonella and E. coli in neonatal diarrheic calves. beni-suef university journal of basic and applied sciences, 5: 45-51.

13. European Pharmacopoeia (1996): Saint Ruffine: Conseil de l'Europe Maisonneuve S.A. NCCLS. National Committee for Clinical Laboratory Standards, Performance Standards for Antimicrobial Susceptibility Testing, 6th edition. Approved Standards, M2-A6, Wayne, Pennsylvania.

14. Feingold, S.M. and Martin, W.T. (1982): Diagnostic Microbiology. $6^{\text {th }}$ Ed. C. V. Mosby Co. St. Louis Toronto, London.

15. Hakim, A.S.; Omara, S.T.; Syame, S.M. and Fouad, E.A (2017): Serotyping, antibiotic susceptibility, and virulence genes screening of Escherichia coli isolates obtained from diarrheic buffalo calves in Egyptian farms, Veterinary World, 10(7): 769-773

16. Helander, I.M.; Alakomi, H.L. and Larva-Kala K. (1998) Characterization of the action of selected essential oil components on Gram negative bacteria. J .Agri Food Chem. 46: 3590-3595.

17. Imelouane, B.; Amhamdi, H.; wathelet, J.p.; Ankit, M.; khelid k. and El bachiri, A. (2009): Chemical composition and antimicrobial activity of essential oil of Thyme (Thymus vulgaris) from Eastern Morocco. Int. J. Agric. Biol., 11(2): 205-208

18. Irena, Ž; Dušan, M.; Ružica, A and Jasna, I . (2009): Antibacterial activity of essential oils of some lamiaceae family species isolated by different methods. Zbornik radova Tehnološkog Fakulteta u Leskovcu, (5): 20-26.

19. Izzo, M.M.; Kirkland, P.D.; Mohler, V.L. and Perkins, N.R. (2011): Prevalence of major enteric pathogens in Australian dairy calves with diarrhea. Australian Veterinary Journal, 89(5):167-73

20. Karczmarczyk, M.; Walsh, C.; Slowey, R.; Leonard, N. and Fanning, S. (2011): Molecular Characterization of MultidrugResistant Escherichia coli Isolates from Irish Cattle Farms. Appl Environ Microbiol., 77 (20): 7121-7127.

21. Killingsworth, L.M. and Savory, J. (1972): Manual Nephelometric Methods for Immunochemical determination of immunoglobulins IgG, IgA and IgM. Clin. Chem., 18 (4) 335-339.

22. Koneman, E.W.; Allem, S.D.; Darula, M.W.; Schrechenberger, P.C. and Win, W.C. (1997): color atlas and textbook of diagnostic microbiology. $5^{\text {th }} \mathrm{Ed}$. Lippincott Philadelphia, network.

23. Lopez-Romero, J.C.; González-Ríos,H.;Borges, A. and Simões, M. (2015) : Antibacterial Effects and Mode of Action of Selected Essential Oils Components against Escherichia coli and Staphylococcus aureus. Evidence-Based Complementary and Alternative Medicine, (2015): 1-9.

24. MacFaddin, J.E. (1980): Biochemical tests for identification of medical bacteria. $2^{\text {nd }} \mathrm{Ed}$. Williams and Wilkins Company, Baltimore, USA.

25. Mashak, Z. (2018): Virulence genes and phenotypic evaluation of the antibiotic resistance of vero toxin producing Escherichia coli recovered from milk, meat, and vegetables. Jundishapur J Microbiol., 11(5): 1-7.

26. Masud, M.A.; Fakhruzzaman, M.; Rahman, M.M.; Shah, M.M. and Nazir, K.H.M.N.H. (2012): Isolation of Escherichia coli from apparently healthy and diarrheic calves in Dinajpur area in Bangladesh and their antibiogram. J. Bangladesh Soc. Agric. Sci. Technol., 9(1\&2): 45-48.

27. Mosaad, A.A.; Ibrahim, E.M.; Akeila, M.A. and Abdelrahem, S.M. (2008): Studies on the Escherichia coli virulence factors coding heat stable toxin, Verotoxin and gene for attaching and effacing associated with diarrhea in calves using PCR. Minufiya Vet. J., 5 (1): 287-301.

28. Ozkaya, S.; Erbas, S.; Ozkan, O.; Baydar, H. and Aksu, T. (2018): Effect of supplementing milk replacer with aromatic oregano (Oreganum onites L.) water on performance, immunity and general health profiles of Holstein calves. Animal Production Science, 58: 1892-1900.

29. Palomino, J.C.; Martin, A.; Gurra, H.; Swings, J. and Portaels, F. (2002): Simple and inexpensive method for detection of drug resistance in Mycobacterium turbeculo Resazurin microtiter assay plate. Res. Adv. Antimicrob agents chemother., 4: 9-38.

30. Quinn, P.J.; Markey, B.K.; Carter, M.E.; Donnelly, W.J.C.; Leonard, F.C and Maguire, D. (2002): Veterinary Microbiology and Microbial Diseases, 2ndEdition. Wiley Black well science, London: 110-111.

31. Santos, F.H.; De Paula, M.R.; Lezier, D.; Silva, J.T.; Santos, G. and Bittar, C.M.(2015): Essential oils for dairy calves effects on performance, scours, rumen fermentation and intestinal fauna. Animal, 9 (6): 958-65.

32. Santurio, D.F.; Jesus, F.P.K.; Zanette, R.A.; Schlemmer, K.B.; A. and Fries, L.L.M. (2014): Antimicrobial Activity of the Essential Oil of Thyme and of Thymol against Escherichia coli Strains. Acta Scientiae Veterinariae., 42 (1): 1-4.

33. Sikkema, J.; De Bont, J.A.M. and Poolman, B. (1994): Interactions of cyclic hydrocarbons with biological membranes. J .Biol Chem., 269: 8022-8028.

34. SPSS, (2013): IBM Corp. Released 2013. IBM SPSS Statistics for Windows, Version 22.0. Armonk, NY: IBM Corp.

35. Srivani, M.; Reddy, Y.N.; Subramanyam, K.V.; Reddy, M R. and Rao, T.S. (2017): Prevalence and antimicrobial resistance pattern of Shiga toxigenic Escherichia coli in diarrheic buffalo calves. VetWorld, 10 (7): 774-778.

36. Stenutz, R.; Weintraub, A. and Widmalm, G. (2006): The structures of Escherichia coli O-polysaccharide antigens. FEMS Microbiology Reviews, 30 (3): 382-403.

37. Vakili, A.R.; Khorrami, B.; Mesgaran, M.D. and Parand, E. (2013): The Effects of Thyme and Cinnamon Essential Oils on Performance Rumen Fermentation and Blood Metabolites in Holstein Calves Consumin

38. Vandeputte, S.; Detilleux, J.; Care, S.; Bradfer, B.; Guyot, H. and Rollin, F. (2010): Evaluation of a bovine concentrated lactoserum for preventing neonatal diarrhea in belgian blue calves. The Open Vet. Sci.J., (4): 36-40.

39. Yeshiwas, T.and Fentahun, W. M. (2017): The prevalence of E. coli from diarrheic calves and their antibiotic sensitivity test in selected dairy farms of Debre Zeit, Ethiopia. Adv Biotech \& Micro., 6 (1): 1-9.

40. Zeng, Z.; Zhang, S.; Wang, H. and Piao, X. (2015). Essential oil and aromatic plants as feed additives in non-ruminant nutrition: A review. J. Anim. Sci. Biotechnol., 6 (1): 